\title{
Structural features of mono and dimetallic complexes of palladium combining two types of aromatic NHC ligands
}

\begin{abstract}
Sergio Gonell, ${ }^{*[a]}$ Eduardo Peris, ${ }^{[b]}$ and Macarena Poyatos ${ }^{*[b]}$
Abstract: A family of palladium complexes that combine two types of aromatic $\mathrm{N}$-heterocyclic carbene $(\mathrm{NHC})$ ligands has been prepared starting from dinuclear palladium complexes. Two of the complexes are mono-metallic and contain a pyrene-based mono-NHC and a benzimidazolylidene ligand. The other two are dimetallic and combine a bridging pyrene-based bis-NHC ligand with benzimidazolylidene ligands. All new complexes therefore contain two types of NHC ligands that differ in the size of their aromatic backbones coordinated to the same metal center. All complexes have been characterized and the molecular structure of two of them has been confirmed by X-Ray diffraction studies.
\end{abstract}

\section{Introduction}

Poly-metallic compounds represent an interesting type of complexes that have been object of intense research during the last years. The fact that different metal centers are bridged through a common ligand, and therefore located in a close proximity, can provide synergetic effects and unique properties, which are often not accessible by combining the mono-metallic analogs. ${ }^{[1-2]}$ When designing this type of compounds, one crucial parameter to consider is the type of ligand used to bridge/connect the different metal centers. In this regard, properties as flexibility, electronic communication and donor ability of the bridging ligands need to be finely tuned in order to enhance the benefits of the multimetallic compounds. ${ }^{[3]}$ Although a number of ligands have been used in order to achieve this goal, $\mathrm{N}$-heterocyclic carbenes $(\mathrm{NHCs})^{[4-5]}$ are located in a privileged position because their synthetic versatility and good donating ability usually yield complexes with higher stability and improved catalytic properties. $^{[2,6-7]}$ Furthermore, the rigid nature of some poly-NHCs allows stablishing fixed distances between the metal centers connected by these polydentate ligands. ${ }^{[8-9]}$ In particular, facially opposed bis-NHCs (Janus-type bis-carbenes, Scheme 1) have been widely used to construct bimetallic complexes ${ }^{[10-11]}$ and organometallic polymers. ${ }^{[10,12]}$

[a] Dr. Sergio Gonell

Department of Chemistry, CB 3290

University of North Carolina at Chapel Hill

Chapel Hill, NC 27599-3290, United Sates of America.

E-mail: sgonell@uji.es (http://www.iciq.org/staff/gonell-sergio/)

[b] Prof. Eduardo Peris, Dr. Macarena Poyatos

Institute of Advanced Materials (INAM). Universitat Jaume I.

Av. Vicente Sos Baynat s/n. Castellón. E-12071. Spain.

E-mail: eperis@uji.es (http://www.inam.uji.es/users/eduardo-peris)

poyatosd@uji.es (http://www.inam.uji.es/users/macarena-poyatos)

Supporting information for this article is given via a link at the end of the document.
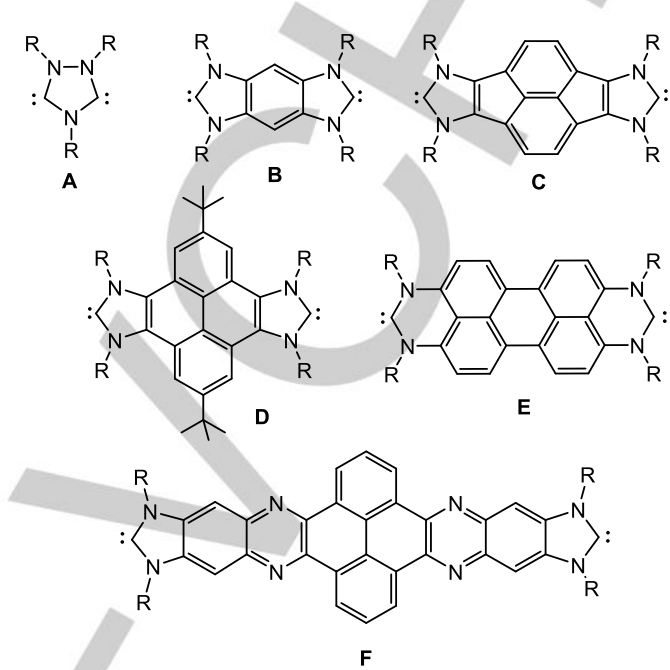

Scheme 1. Selected Janus type bis-NHC ligands with different polyaromatic cores

One general strategy for synthesizing geometrically isolated bis$\mathrm{NHCs}$ is the direct annulation between the two carbenic moieties (such as $\mathbf{A}$ in Scheme 1), ${ }^{2,11,13]}$ or the introduction of planar fused-aromatic groups between the two carbene moieties, such as benzene $(\mathbf{B}),{ }^{[14-15]}$ pyracene $(\mathbf{C}),{ }^{[16-17]}$ pyrene $(\mathbf{D}),{ }^{[18-20]}$ perylene $(\mathbf{E})^{[21]}$ or quinoxalinophenanthrophenazine (F). ${ }^{[22]}$ Janus-type benzobisoxazolin-2-ylidene ligands $^{[23]}$ and dianionic bis(malonate-NHCs) ${ }^{[15,24]}$ have also been prepared for this purpose.

All these ligands have allowed establishing fixed distances between the metals ranging from 6 to $24 \AA$. The presence of the bridging polyaromatic moieties also introduce important features in the catalytic properties of the complexes, due to supramolecular interactions (mostly due to $\pi-\pi$-stacking interactions) between the polyaromatic ligands and the substrates, and to the self-association of the catalysts. ${ }^{[25]}$ Not less important is that the presence of the polyaromatic moieties provides new photophysical properties to the complexes (mainly fluorescence), thus affording an interesting approach to combine them with the intrinsic features of transition metals. In this regard, several mono$\mathrm{NHCs}$ containing an annulated polyaromatic backbone have been synthesized (Scheme 2) and coordinated to transition metals furnishing new complexes with very interesting photophysical properties. ${ }^{[18,26-33]}$

In this work, we aimed to prepare a family of palladium complexes that combine pyrene-based mono- and bis-NHC ligands with benzimidazolylidenes. We thought that providing an efficient route for combining mono-NHC ligands with bis-NHC ligands would provide new examples of complexes decorated with aromatic fragments. Other mononuclear palladium complexes that contain two NHCs with different type of annulated polyaromatic groups, 
namely benzimidazolylidene and benzoxazolinylidene ligands, are described in the literature. ${ }^{[23]}$<smiles>[R]N1CN([R])c2ccccc21</smiles><smiles>[R]N1CN([R])c2cc3ccccc3cc21</smiles><smiles>[R]N1CN([R])c2cccc3cccc1c23</smiles><smiles>[R]N1CCN([R])c2c1c1ccccc1c1ccccc21</smiles><smiles></smiles><smiles>[R]C1=Cc2c3c4c(ccc(ccc2=4)=C([R])N([R])CN3[R])=C1</smiles>

$\mathrm{R}^{\prime}=\mathrm{H}, t \mathrm{Bu}$

Scheme 2. Selected examples of mono-NHC ligands decorated with polyaromatic backbones

\section{Results and Discussion}

Synthesis and Characterization. For the preparation of our complexes with mixed aromatic-NHC ligands, we thought that a good strategy would be to use halide-bridged palladium (II) dinuclear complexes, since the addition of an $L$ type ligand should provide direct access to the desired products. Our palladiumbenzimidazolylidene complexes were obtained following the procedure depicted in Scheme $3{ }^{\left[{ }^{34]}\right]}$ which involves the reaction of the benzimidazolium salts $\mathbf{A}(\mathbf{A}-\mathbf{E t}$ or $\mathbf{A}-\boldsymbol{n P r})$ with $\mathrm{Pd}(\mathrm{OAc})_{2}$ in the presence of $\mathrm{NaBr}$. This procedure allowed the isolation of the desired complexes in excellent yields (85 and $77 \%$ yield for 1 -Et and $\mathbf{1}-\boldsymbol{n P r}$, respectively). Complexes of type $\mathbf{1}$ were characterized by NMR spectroscopy, mass spectrometry and gave satisfactory elemental analysis. Mass spectrometry provided evidence of the dinuclear nature of these compounds, as the prominent peak corresponds to $[\mathrm{M}-\mathrm{Br}+\mathrm{MeCN}]^{+}$species. The ${ }^{13} \mathrm{C}$ NMR spectra show the distinctive signals due to the metallated carbene carbon (157.3 and 157.7 ppm for 1-Et and 1-nPr, respectively).

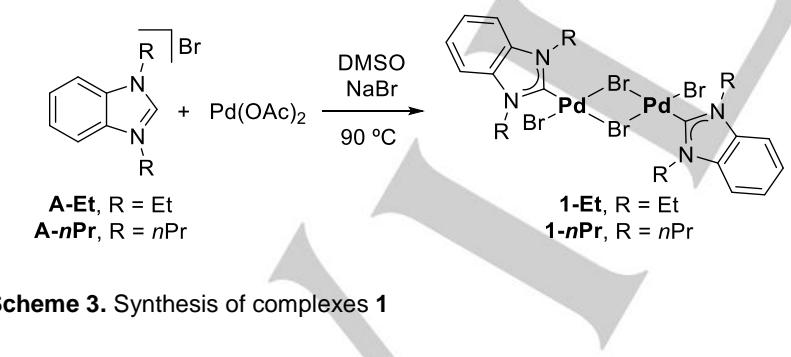

The molecular structure of complex 1-Et was unambiguously confirmed by single crystal X-ray diffraction studies (Figure 1). The molecule consists of a dinuclear palladium complex, in which each palladium center is coordinated to one benzimidazolylidene ligand. One terminal bromide and two bridging bromide ligand complete the pseudo-square planar coordination sphere about each metal fragment. As expected, the Pd1-Br2 bond distance, trans to the NHC ligand, is longer than that observed for the other type of $\mathrm{Pd}-\mathrm{Br}$ bonds of the molecule due to the strong trans influence of the NHC ligand. The coordination planes of the two palladium centers are not coplanar (the angle between them is $\left.13.76(7)^{\circ}\right)$, providing a slightly bent structure (Figure 1, bottom). The angle between the planes defined by the two benzimidazolylidene ligands is $32.0(2)^{\circ}$. These two structural features are in contrast with molecular structures of similar type of dinuclear complexes based on $\mathrm{NHCs}$ of $\mathrm{Pd}^{[34-35]}$ or $\mathrm{Rh}^{\left[{ }^{[36]}\right.}$ in which the coordination planes of the metal center are coplanar and the planes defined by the NHC ligands are parallel. We think that the relative small size of the $\mathrm{N}$-Et groups at the $\mathrm{NHC}$, compared with the $\mathrm{N}$-substituents present in related complexes (dipp, $\operatorname{Pr}$ and $\mathrm{Bn}$ ), makes the environment around the metal center less sterically constrained, thus allowing a higher degree of rotation to the ligands. The angle between the coordination plane of the palladium center and the plane defined by the azole ring is $79.33(12)^{\circ}$. The $\mathrm{Pd}-\mathrm{C}_{\text {carbene }}$ distance is $1.955(5) \AA$ and the distance between the two palladium centers is $3.5778(7) \AA$. The crystal packing of 1-Et reveals $\pi-\pi$ stacking interactions between pairs of dinuclear complexes, located a distance of $3.501 \AA$. The CCDC reference number for complex 1-Et was assigned as 1921386.
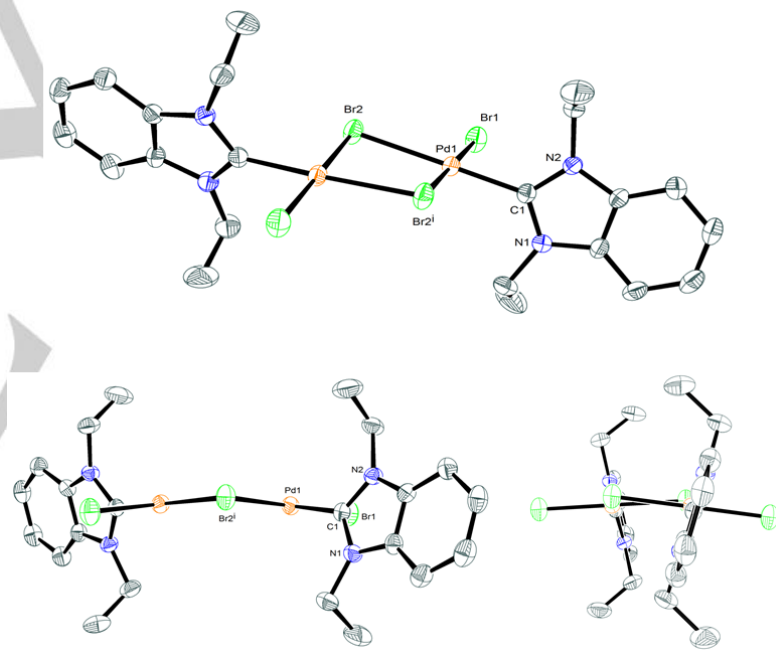

Figure 1. Different perspectives of the molecular structure of 1-Et. Hydrogen atoms and solvent $\left(\mathrm{CHCl}_{3}\right)$ omitted for clarity. Thermal ellipsoids are shown at the $50 \%$ level of probability. Selected bond distances (angstroms) and angles (degrees): Pd1-C1 1.955(5), Pd1-Br1 2.4160(6), Pd1-Br2 2.5289(6), Pd1-Br2 2.4478(6), C1-Pd1-Br2 177.01(14), Br1-Pd1-Br2 179.84(2), C1-Pd1-Br1 89.93(14), Br2-Pd1-Br2 87.17(2).

Dinuclear $\mathrm{Pd}(\mathrm{II})-\mathrm{NHC}$ complexes have proved to be excellent precursors for the synthesis of a range of monocarbene complexes. ${ }^{[34-35,37]}$ In our case, we used complexes $\mathbf{1}$ in combination with our previously reported pyrene-based monoand bis-NHCs for preparing new palladium complexes containing two types of $\mathrm{NHC}$ ligands decorated with aromatic moieties. 
Mono-palladium complexes 2 were synthesized through a transmetallation strategy (Scheme 4). ${ }^{[38]}$ Silver-carbene complexes based on pyrene were generated in situ by treating the mono-azolium salts $(\mathbf{B})^{[39]}$ with $\mathrm{Ag}_{2} \mathrm{O}$. Transmetallation by addition of the palladium dinuclear complexes (1) provided the desired mono-palladium complexes (2) in good yields after purification by column chromatography.
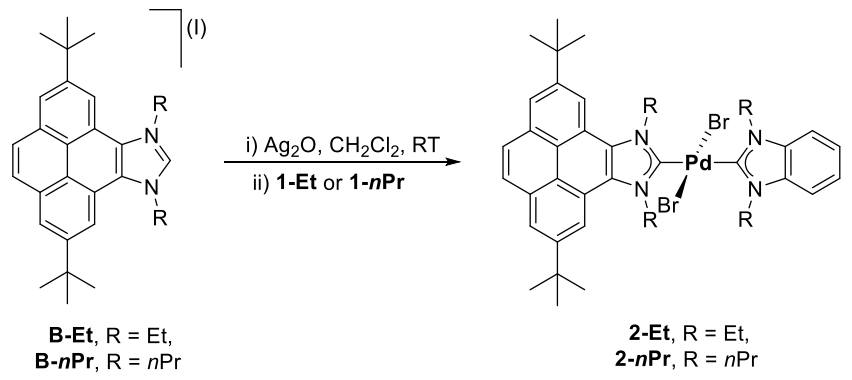

Scheme 4. Synthesis of monometallic complexes 2

The isolation of the di-palladium complexes $\mathbf{3}$ was better achieved by means of a deprotonation route (Scheme 5 ). The reaction of the pyrene-based bis-imidazolium salts $(\mathbf{C})^{[19]}$ with the palladium dinuclear complexes (1) in the presence of $\mathrm{KOtBu}$ yielded the dimetallic complexes $\mathbf{3}$, which were isolated as yellow powders after purification by column chromatography. Complexes of type $\mathbf{2}$ and $\mathbf{3}$ were characterized by means of mass spectrometry, NMR spectroscopy, and gave satisfactory elemental analysis.
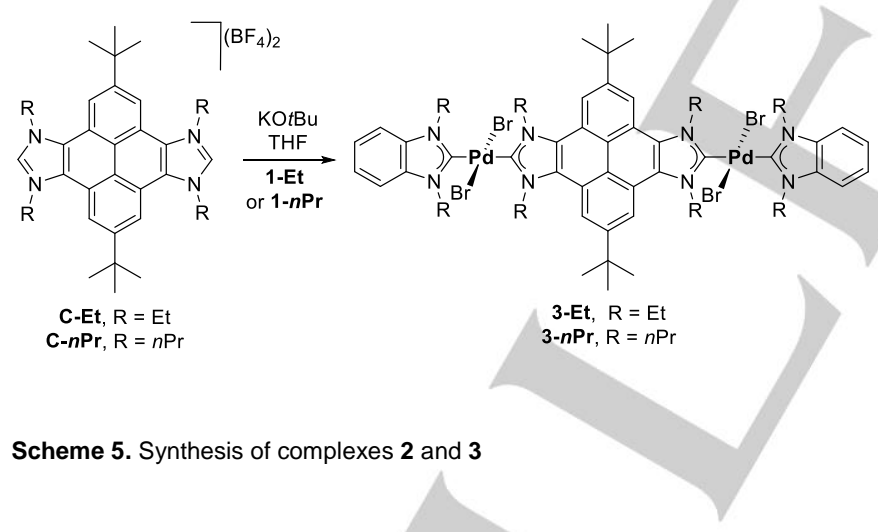

The ${ }^{1} \mathrm{H}$ NMR spectrum of the monometallic complexes 2 is consistent with their expected two-fold symmetry, as exemplified by the equivalence of the signals corresponding to the protons of the pyrene fragment. Interestingly, from the two possible isomers (cis or trans) the trans one was obtained selectively. This is evident from ${ }^{1} \mathrm{H}$ NMR spectroscopy, as the protons of the $\mathrm{N}-\mathrm{CH}_{2}$ groups are equivalent for each carbene ligand, while they should be diasterotopic for the cis isomer.

The ${ }^{1} \mathrm{H}$ NMR spectra of the dimetallic complexes $\mathbf{3}$ indicates the formation of compounds with highly symmetric structures, as only one resonance is observed for the four aromatic protons of the pyrene fragment. No diastereotopicity is observed for the signals corresponding to the protons of the $\mathrm{N}-\mathrm{CH}_{2}$ groups, thus the formation of cis isomers can be ruled out.

Another indication that the two different NHCs are mutually trans in complexes $\mathbf{2}$ and $\mathbf{3}$ arises from the ${ }^{13} \mathrm{C}$ NMR spectra, as the resonances due to the two metallated carbene atoms appear at 181.2-181.0 and 178.8-176.6 ppm, in the typical region shown for trans-bis-NHC complexes of the type $\mathrm{PdX}_{2}(\mathrm{NHC})_{2}{ }^{[40]}$ (cis-NHCs appear at higher fields, $\sim 170 \mathrm{ppm}) .{ }^{[41]}$

The ${ }^{13} \mathrm{C}_{\text {carbene }}$ NMR signal of the 1,3 diisopropylbenzimidazolylidene ( $\mathrm{Pr}_{2}$-bimy) ligand (so-called HEP value) in complexes of the type trans- $\left[\mathrm{PdBr}_{2}\left(\mathrm{Pr}_{2}-\right.\right.$ bimy $\left.)(\mathrm{NHC})\right]$ and $\left[\mathrm{Pd}_{2} \mathrm{Br}_{4}(\mathrm{Pr} \text {-bimy })_{2}(\mathrm{diNHC})\right]$ has been proposed by Huyhn and co-workers for the evaluation of the donor strength of transstanding mono- $\mathrm{NHC}^{[42]}$ and dicarbene-bridged ligands, ${ }^{[43]}$ respectively. Strong donating ligands induce downfield shifts while weaker donating ones would lead to higher field HEP signals.

Complexes 2 and $\mathbf{3}$ differ from the proposed probes in that they contain either 1,3-di-ethylbenzimidazolylidene ( $\mathrm{Et}_{2}$-bimy) or 1,3di-n-propylbenzimidazolylidene ( $n \mathrm{Pr}_{2}$-bimy) ligands instead of the $\mathrm{Pr}_{2}$-bimy reporter ligand. Using our benzimidazolylidene-based ligands as probes, we can observe that there is a very small difference between the ${ }^{13} \mathrm{C}_{\text {carbene }} \mathrm{NMR}$ signals for these ligands in $\mathbf{2}(181.2 \mathrm{ppm})$ and $\mathbf{3}(181.0 \mathrm{ppm})$. This very small difference might indicate that the pyrene-based mono- and bis-NHC ligands have very similar electron-donating character, which is in agreement with our previous findings using other methodologies.

The molecular structure of complex 3-Et was confirmed by single crystal X-ray diffraction studies (Figure 2). The molecule consists of a pyrene-based bis-imidazolylidene ligand connecting two palladium centers that complete their coordination sphere with two (trans) bromide ligands and a benzimidazolylidene ligand. The planes defined by the benzimidazolylidene ligand and by the pyrene moiety are quasi-coplanar $\left(3.59(9)^{\circ}\right)$, and quasiperpendicular to the coordination plane of the palladium center, with dihedral angles of $85.57(12)^{\circ}$ and $89.02(14)^{\circ}$. The Pd1-C1 and the Pd1-C2 bond distances are 2.023(4) $\AA$ and 2.018(4) $\AA$, respectively, in agreement with bond distances reported for palladium complexes containing two $\mathrm{NHC}$ ligands in a relative trans fashion. ${ }^{[41]}$

The through space $\mathrm{Pd}-\mathrm{Pd}$ distance is $13.1848(6) \AA$, in the range of those observed for $\mathrm{Rh},{ }^{[19]} \mathrm{Ir}^{\left[{ }^{[19]}\right.} \mathrm{Ru}^{[18]}$ and $\mathrm{Pt}{ }^{[20,}{ }^{44]}$ homobimetallic complexes supported by the pyrene-bisimidazolylidene ligand. In contrast with the previous complexes bearing pyrene-based NHC ligand, the crystal structure does not show intermolecular $\pi-\pi$ stacking interactions 3-Et. The CCDC reference number for complex 3-Et was assigned as 1921387.

The photophysical properties of the metal complexes 1, 2 and 3Et were studied in dichloromethane solution at $298 \mathrm{~K}$. The palladium dinuclear complexes 1 show almost superimposable absorption spectra with $\lambda_{\max }$ at 255, 291 and $349 \mathrm{~nm}$ (see Figure S1 in the Supporting Information), and exhibit negligible fluorescence emission.

Complexes 2 and 3-Et exhibit an intense absorption band with $\lambda_{\max }$ at $245 \mathrm{~nm}$. The bis-NHC complex 3-Et also exhibits a less intense vibronic-structured band at 320-360 nm, which can be assigned to pyrene-centered transitions (see Figure S2 in the 
Supporting Information). Complexes 2 and 3-Et featured vibronically resolved bands in their emission spectra but exhibit very low fluorescence emission under the conditions we performed the studies.

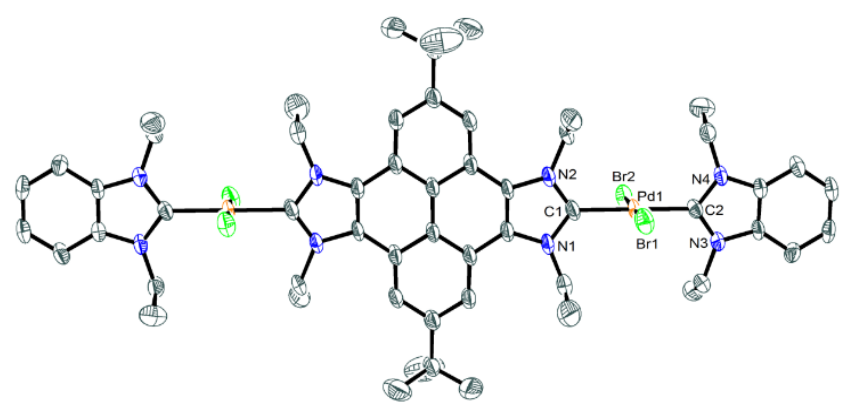

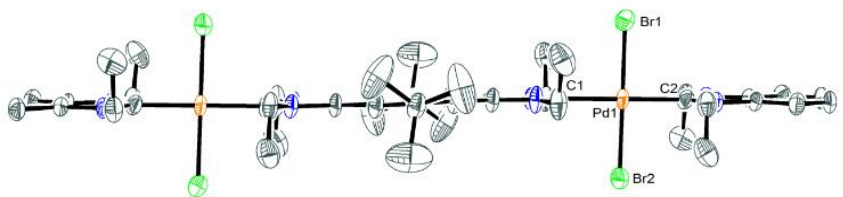

Figure 2. Two perspectives of the molecular structure of 3-Et. Hydrogen atoms and solvent $\left(\mathrm{CHCl}_{3}\right)$ omitted for clarity. Thermal ellipsoids are shown at the $50 \%$ level of probability. Selected bond distances (angstroms) and angles (degrees): Pd1-C1 2.023(4), Pd1-C2 2.018(4), Pd1-Br1 2.4214(6), Pd1-Br2 2.4315(6), C1-Pd1-C2 179.68(19), Br1-Pd1-Br2 178.73(2), C1-Pd1-Br1 91.37(14), C2Pd1-Br2 91.64(13)

\section{Conclusions}

In summary, we have reported the synthesis and characterization of a new family of mono- and dimetallic palladium complexes bearing two types of $\mathrm{NHCs}$ differing in the size of the aromatic annulated backbone. Geometrical isomers locating the two NHCs in a relative trans configuration were obtained selectively, avoiding the generation of other potential isomers. We think that with this work we provided an efficient route for the trans-selective preparation of palladium complexes with two different types of $\mathrm{NHC}$ ligands. We think that this synthetic procedure will improve the chances to obtain NHC-based complexes with interesting photophysical properties by, for instance, extending it to $\mathrm{Pt}(\mathrm{II})$ complexes.

\section{Experimental Section}

General methods. The imidazolium salt A-Et, ${ }^{[45]} \mathbf{B}-\mathbf{E t},{ }^{[39]} \mathbf{B}-n \mathbf{P r},{ }^{[39]} \mathbf{C}$ $\mathbf{E t}^{[19]}$ and $\mathbf{C}-\boldsymbol{n} \mathbf{P r}{ }^{[19]}$ were prepared as previously reported. All operations were carried out by using standard Schlenk techniques under nitrogen atmosphere unless otherwise stated. Anhydrous solvents were dried using a solvent purification system (SPS M BRAUN) or purchased from Aldrich and degassed prior to be used by purging with nitrogen and kept over molecular sieves. All other reagents were used as received from commercial suppliers. NMR spectra were recorded on a Bruker 300 or 400
$\mathrm{MHz}$, or in a Varian Innova $500 \mathrm{MHz}$, using $\mathrm{CDCl}_{3}$ or DMSO- $d_{6}$ as solvents. Electrospray mass spectra (ESI-MS) were recorded on a Micromass Quatro LC instrument; nitrogen was employed as drying and nebulizing gas. Exact mass analysis was realized using Q-TOF premier mass spectrometer with electrospray source (Waters, Manchester, UK) operating at a resolution of ca. 16000 (fwhm). Elemental analyses were carried out on a TruSpec Micro Series. UV-Visible absorption spectra were recorded on a Varian Cary 300 BIO spectrophotometer using dichloromethane under ambient conditions. Emission spectra were recorded on a modular Horiba FluoroLog-3 spectrofluorometer employing dichloromethane.

Synthesis of A-nPr. A thick-walled Schlenk tube fitted with a Teflon cap was charged with benzimidazole $(424 \mathrm{mg}, 3.52 \mathrm{mmol}), \mathrm{NaHCO}_{3}(606.4$ $\mathrm{mg}, 7.22 \mathrm{mmol}$ ) and acetonitrile $(5 \mathrm{~mL})$. The mixture was stirred at $90 \stackrel{\circ}{\circ} \mathrm{C}$ during $1 \mathrm{~h}$. After that, $n$-propylbromide $(1.93 \mathrm{~mL}, 21 \mathrm{mmol})$ was added at room temperature and the mixture was further heated at $90{ }^{\circ} \mathrm{C}$ overnight. The solvent was removed under vacuum. The brownish solid residue was suspended in $\mathrm{CH}_{2} \mathrm{Cl}_{2}$ and filtered to remove insoluble inorganic salts. Precipitation of the filtrate with a mixture $\mathrm{CH}_{2} \mathrm{Cl}_{2} /$ diethyl ether afforded compound A-nPr as a white solid. Yield: $990 \mathrm{mg}, 99 \% .{ }^{1} \mathrm{H} \mathrm{NMR}(300 \mathrm{MHz}$, dmso- $\left.d_{6}\right): \delta 10.00(\mathrm{~s}, 1 \mathrm{H}, \mathrm{NCHN}), 8.13\left(\mathrm{dd},{ }^{3} J_{\mathrm{H}-\mathrm{H}}=6.2 \mathrm{~Hz},{ }^{4} \mathrm{~J}_{\mathrm{H}-\mathrm{H}}=3.1 \mathrm{~Hz}\right.$ $\left.2 \mathrm{H}, \mathrm{C} H_{\text {arom }}\right), 7.69\left(\mathrm{dd},{ }^{3} \mathrm{H}_{\mathrm{H}-\mathrm{H}}=6.3 \mathrm{~Hz},{ }^{4} \mathrm{~J}_{\mathrm{H}-\mathrm{H}}=3.1 \mathrm{~Hz}, 2 \mathrm{H}, \mathrm{CH}_{\text {arom }}\right), 4.50(\mathrm{t}$, $\left.{ }^{3} J_{\mathrm{H}-\mathrm{H}}=7.1 \mathrm{~Hz}, 4 \mathrm{H}, \mathrm{NCH}_{2} \mathrm{CH}_{2} \mathrm{CH}_{3}\right), 2.01-1.89\left(\mathrm{~m}, 4 \mathrm{H}, \mathrm{NCH}_{2} \mathrm{CH}_{2} \mathrm{CH}_{3}\right), 0.92$ $\left(\mathrm{t},{ }^{3} \mathrm{H}_{\mathrm{H}-\mathrm{H}}=7.4 \mathrm{~Hz}, 6 \mathrm{H}, \mathrm{NCH}_{2} \mathrm{CH}_{2} \mathrm{CH}_{3}\right) .{ }^{13} \mathrm{C} \mathrm{NMR}\left(75 \mathrm{MHz}\right.$, dmso- $\left.d_{6}\right): \delta 142.1$ ( $\mathrm{NCHN}), 131.1\left(\mathrm{C}_{\mathrm{q}}\right), 126.4\left(\mathrm{CH}_{\text {arom }}\right), 113.7\left(\mathrm{CH}_{\text {arom }}\right), 48.0\left(\mathrm{NCH}_{2} \mathrm{CH}_{2} \mathrm{CH}_{3}\right)$, $22.0 \quad\left(\mathrm{NCH}_{2} \mathrm{CH}_{2} \mathrm{CH}_{3}\right), \quad 10.6 \quad\left(\mathrm{NCH}_{2} \mathrm{CH}_{2} \mathrm{CH}_{3}\right)$. Anal. Calc. for $\mathrm{N}_{2} \mathrm{C}_{13} \mathrm{H}_{19} \mathrm{Br} \cdot \mathrm{H}_{2} \mathrm{O}$ (301.22): C, 51.83; $\mathrm{H}, 7.03 ; \mathrm{N}, 9.30$. Found: $\mathrm{C}, 51.38 ; \mathrm{H}$, 7.18; N, 8.99. Electrospray MS (20 V, m/z): $203.3\left[\mathrm{M}^{+}\right.$.

General procedure for the synthesis of palladium dinuclear complexes 1. $\mathrm{Pd}(\mathrm{OAc})_{2}$ (397 mg, $1.77 \mathrm{mmol}, 1$ equiv.), $\mathrm{NaBr}(865 \mathrm{mg}$, $7.08 \mathrm{mmol}, 4$ equiv.) and the corresponding imidazolium salt $(1.77 \mathrm{mmol}$, 1 equiv.) were dissolved in $7 \mathrm{~mL}$ of DMSO and the mixture was stirred at $90 \stackrel{\circ}{ } \mathrm{C}$ during $24 \mathrm{~h}$. Then, the solvent was removed under vacuum. The solid residue was dissolved in $\mathrm{CH}_{2} \mathrm{Cl}_{2}(300 \mathrm{~mL})$ and the solution was washed with water $(4 \times 200 \mathrm{~mL})$. The organic phase was dried with $\mathrm{MgSO}_{4}$, filtered and the solvent was removed under vacuum. Precipitation from a mixture $\mathrm{CH}_{2} \mathrm{Cl}_{2}$ /hexane afforded the corresponding complex as an orange solid.

Synthesis of 1-Et. Yield: $732 \mathrm{mg}, 85 \% .{ }^{1} \mathrm{H}$ NMR $\left(300 \mathrm{MHz}\right.$, DMSO- $\left.d_{6}\right): \delta$ $7.73\left(\mathrm{dd},{ }^{3} J_{\mathrm{H}-\mathrm{H}}=6.0,{ }^{4} \mathrm{~J}_{\mathrm{H}-\mathrm{H}}=3.1 \mathrm{~Hz}, 4 \mathrm{H}, \mathrm{CH} H_{\text {arom }}\right), 7.36\left(\mathrm{dd},{ }^{3} \mathrm{~J}_{\mathrm{H}-\mathrm{H}}=6.1 \mathrm{~Hz}\right.$, $\left.{ }^{4} \mathrm{JH}_{\mathrm{H}-\mathrm{H}}=3.1 \mathrm{~Hz}, 4 \mathrm{H}, \mathrm{CH}_{\text {arom }}\right), 4.80\left(\mathrm{q},{ }^{3} \mathrm{H}-\mathrm{H}=7.2 \mathrm{~Hz}, 8 \mathrm{H}, \mathrm{NCH}_{2} \mathrm{CH}_{3}\right), 1.56$ (t, $\left.{ }^{3} \mathrm{H}_{\mathrm{H}-\mathrm{H}}=7.2 \mathrm{~Hz}, 12 \mathrm{H}, \mathrm{NCH}_{2} \mathrm{CH}_{3}\right) .{ }^{13} \mathrm{C} \mathrm{NMR}\left(75 \mathrm{MHz}\right.$, dmso- $\left.d_{6}\right): \delta 157.3(\mathrm{Pd}-$ $\left.C_{\text {carbene }}\right), 133.3\left(\mathrm{C}_{\mathrm{q}}\right), 123.2\left(\mathrm{CH}_{\text {arom }}\right), 110.8\left(\mathrm{CH}_{\text {arom }}\right), 43.1\left(\mathrm{NCH}_{2} \mathrm{CH}_{3}\right), 14.0$ $\left(\mathrm{NCH}_{2} \mathrm{CH}_{3}\right)$. Anal. Calc. for $\mathrm{Pd}_{2} \mathrm{Br}_{4} \mathrm{~N}_{4} \mathrm{C}_{22} \mathrm{H}_{28}$ (880.95): C, 30.00; H, 3.20; N, 6.36. Found: $\mathrm{C}, 29.79 ; \mathrm{H}, 3.65 ; \mathrm{N}, 6.26$. Electrospray MS (20 V, $\mathrm{m} / \mathrm{z}): 842.0$ $[\mathrm{M}-\mathrm{Br}+\mathrm{MeCN}]^{+}$.

Synthesis of 1-nPr. Yield: $634 \mathrm{mg}, 77 \% .{ }^{1} \mathrm{H}$ NMR $\left(500 \mathrm{MHz}\right.$, DMSO- $\left.d_{6}\right)$ : $\delta 7.73\left(\mathrm{dd},{ }^{3} \mathrm{~J}_{\mathrm{H}-\mathrm{H}}=6.0 \mathrm{~Hz},{ }^{4} \mathrm{~J}_{\mathrm{H}-\mathrm{H}}=3.0 \mathrm{~Hz}, 4 \mathrm{H}, \mathrm{CH}\right.$ arom $), 7.34\left(\mathrm{dd},{ }^{3} \mathrm{~J}-\mathrm{H}=6.0\right.$ $\left.\mathrm{Hz},{ }^{4} \mathrm{JH}_{\mathrm{H}}=3.0 \mathrm{~Hz}, 4 \mathrm{H}, \mathrm{CH}_{\text {arom }}\right), 4.78-4.57\left(\mathrm{~m}, 8 \mathrm{H}, \mathrm{NCH}_{2} \mathrm{CH}_{2} \mathrm{CH}_{3}\right), 2.16-$ $2.08\left(\mathrm{~m}, 8 \mathrm{H}, \mathrm{NCH}_{2} \mathrm{CH}_{2} \mathrm{CH}_{3}\right), 1.01$ (t, $\left.{ }^{3} \mathrm{~J}-\mathrm{H}=7.3 \mathrm{~Hz}, 12 \mathrm{H}, \mathrm{NCH}_{2} \mathrm{CH}_{2} \mathrm{CH}_{3}\right)$. ${ }^{13} \mathrm{C}$ NMR $\left(75 \mathrm{MHz}\right.$, dmso- $\left.d_{6}\right)$ : $\delta 157.7$ (Pd- $\left.C_{\text {carbene }}\right), 133.8\left(C_{\mathrm{q}}\right), 123.1$ ( $\left.\mathrm{CH}_{\text {arom }}\right), 110.9$ ( $\left.\mathrm{CH}_{\text {arom }}\right), 49.4\left(\mathrm{NCH}_{2} \mathrm{CH}_{2} \mathrm{CH}_{3}\right), 22.0\left(\mathrm{NCH}_{2} \mathrm{CH}_{2} \mathrm{CH}_{3}\right), 11.2$ $\left(\mathrm{NCH}_{2} \mathrm{CH}_{2} \mathrm{CH}_{3}\right)$. Anal. Calc. for $\mathrm{Pd}_{2} \mathrm{Br}_{4} \mathrm{~N}_{4} \mathrm{C}_{26} \mathrm{H}_{34} \cdot 7 \mathrm{H}_{2} \mathrm{O}$ (1061.15): C, 29.43; H, 4.56; N, 5.28. Found: C, 29.21; H, 4.34; N, 5.34. Electrospray MS (20 $\mathrm{V}, \mathrm{m} / \mathrm{z}): 898.1[\mathrm{M}-\mathrm{Br}+\mathrm{MeCN}]^{+}$.

General procedure for the synthesis of complexes 2. A suspension of the corresponding mono-imidazolium salt (2 equiv.) and $\mathrm{Ag}_{2} \mathrm{O}$ (1 equiv.) in $\mathrm{CH}_{2} \mathrm{Cl}_{2}(15 \mathrm{~mL}$ ) was stirred at room temperature for $2 \mathrm{~h}$ under the exclusion of light. Then 1 was added (1 equiv.) and the resulting mixture was stirred 
at room temperature for $2 \mathrm{~h}$. The suspension was filtered through a pad of Celite and the solvent removed under vacuum. The crude solid was purified by column chromatography. Elution with a 1:1 mixture dichloromethane/hexane afforded the separation of a yellow band that contained complex 2-Et (or 2-nPr). The desired complex was isolated as a yellow solid after precipitation in a mixture of dichloromethane/pentane.

Synthesis of 2-Et. The reaction was carried out with B-Et $(70 \mathrm{mg}, 0.13$ $\mathrm{mmol}), \mathrm{Ag}_{2} \mathrm{O}$ (15.2 mg, $\left.0.065 \mathrm{mmol}\right)$ and 1-Et ( $\left.57 \mathrm{mg}, 0.065 \mathrm{mmol}\right)$. Yield: $55 \mathrm{mg}, 50 \%$. ${ }^{1} \mathrm{H} \mathrm{NMR}\left(500 \mathrm{MHz}, \mathrm{CDCl}_{3}\right): \delta 8.75\left(\mathrm{~d},{ }^{4} \mathrm{~J} \mathrm{H}-\mathrm{H}=1.6 \mathrm{~Hz}, 2 \mathrm{H}\right.$, $\left.\mathrm{CH}_{\text {pyr }}\right), 8.20\left(\mathrm{~d},{ }^{4} \mathrm{~J}_{\mathrm{H}-\mathrm{H}}=1.6 \mathrm{~Hz}, 2 \mathrm{H}, \mathrm{CH}_{\text {pyr }}\right), 8.06\left(\mathrm{~s}, 2 \mathrm{H}, \mathrm{CH}_{\text {pyr }}\right), 7.45(\mathrm{dd}$, ${ }^{3} \mathrm{~J}_{\mathrm{H}-\mathrm{H}}=6.0,{ }^{3} \mathrm{~J}_{\mathrm{H}-\mathrm{H}}=3.1 \mathrm{~Hz}, 2 \mathrm{H}, \mathrm{CH}$ arom), $7.31\left(\mathrm{dd},{ }^{3} \mathrm{JH}_{\mathrm{H}-\mathrm{H}}=6.0,{ }^{3} \mathrm{~J}_{\mathrm{H}-\mathrm{H}}=3.0 \mathrm{~Hz}\right.$, $2 \mathrm{H}, \mathrm{CH}$ arom), $5.73\left(\mathrm{q},{ }^{3} \mathrm{~J}-\mathrm{H}=7.1 \mathrm{~Hz}, 4 \mathrm{H}, \mathrm{NCH}_{2} \mathrm{CH}_{3}\right), 5.01\left(\mathrm{q},{ }^{3} \mathrm{~J}_{\mathrm{H}-\mathrm{H}}=7.3 \mathrm{~Hz}\right.$, $\left.4 \mathrm{H}, \mathrm{NCH}_{2} \mathrm{CH}_{3}\right), 2.07\left(\mathrm{t},{ }^{3} \mathrm{~J}_{\mathrm{H}-\mathrm{H}}=7.3 \mathrm{~Hz}, 6 \mathrm{H}, \mathrm{NCH}_{2} \mathrm{CH}_{3}\right), 1.86\left(\mathrm{t},{ }^{3} \mathrm{H}_{\mathrm{H}-\mathrm{H}}=7.3\right.$ $\left.\mathrm{Hz}, 6 \mathrm{H}, \mathrm{NCH}_{2} \mathrm{CH}_{3}\right), 1.63\left(\mathrm{~s}, 18 \mathrm{H}, \mathrm{C}\left(\mathrm{CH}_{3}\right)_{3}\right) .{ }^{13} \mathrm{C} \mathrm{NMR}\left(126 \mathrm{MHz}, \mathrm{CDCl}_{3}\right): \delta$

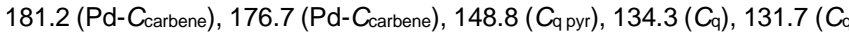
pyr $), 128.7$ ( $\left.C_{\text {q pyr }}\right), 128.2\left(C_{\text {pyr }}\right), 122.6\left(\mathrm{CH}_{\text {arom }}\right), 122.1\left(\mathrm{CH}_{\text {pyr }}\right), 121.0\left(C_{\mathrm{q}}\right.$ pyr), 120.8 ( $\left.C_{\mathrm{q} \text { pyr }}\right), 116.5\left(\mathrm{CH}_{\text {pyr }}\right), 110.2\left(\mathrm{CH}_{\text {arom }}\right), 46.7\left(\mathrm{NCH}_{2} \mathrm{CH}_{3}\right), 43.3$ $\left.\left(\mathrm{NCH}_{2} \mathrm{CH}_{3}\right), 35.4\left(\mathrm{C}_{(\mathrm{CH}}\right)_{3}\right), 31.9\left(\mathrm{C}\left(\mathrm{CH}_{3}\right)_{3}\right), 15.0\left(\mathrm{NCH}_{2} \mathrm{CH}_{3}\right), 14.9$ $\left(\mathrm{NCH}_{2} \mathrm{CH}_{3}\right)$. Anal. Calc. for $\mathrm{PdBr}_{2} \mathrm{~N}_{4} \mathrm{C}_{40} \mathrm{H}_{48}$ (851.08): C, 56.05; H, 5.69; N, 6.58. Found: C, $56.65 ; \mathrm{H}, 5.45 ; \mathrm{N}, 6.43$. Electrospray MS (20 V, $\mathrm{m} / \mathrm{z}): 810.0$ $\left[\mathrm{M}-\mathrm{Br}+\mathrm{CH}_{3} \mathrm{CN}\right]^{+}$

Synthesis of 2-nPr. The reaction was carried out with $\mathrm{B}-n \mathrm{Pr}(136 \mathrm{mg}$ $0.24 \mathrm{mmol}), \mathrm{Ag}_{2} \mathrm{O}(28.2 \mathrm{mg}, 0.12 \mathrm{mmol})$ and $1-n \operatorname{Pr}(112.4 \mathrm{mg}, 0.12 \mathrm{mmol})$. Yield: $125 \mathrm{mg}, 57 \%$. ${ }^{1} \mathrm{H}$ NMR $\left(400 \mathrm{MHz}, \mathrm{CDCl}_{3}\right): \delta 8.67\left(\mathrm{~d},{ }^{4}{ }_{\mathrm{H}-\mathrm{H}}=1.6 \mathrm{~Hz}\right.$, $\left.2 \mathrm{H}, \mathrm{CH}_{\text {pyr }}\right), 8.20$ (d, $\left.{ }^{4} \mathrm{JH}_{\mathrm{H}-\mathrm{H}}=1.6 \mathrm{~Hz}, 2 \mathrm{H}, \mathrm{C} H_{\text {pyr }}\right), 8.06$ (s, $\left.2 \mathrm{H}, \mathrm{CH}_{\text {pyr }}\right), 7.45$ (dd, ${ }^{3} \mathrm{~J}_{\mathrm{H}-\mathrm{H}}=6.0,{ }^{3} \mathrm{JH}_{\mathrm{H}}=3.1 \mathrm{~Hz}, 2 \mathrm{H}, \mathrm{CH}$ arom $), 7.29\left(\mathrm{dd},{ }^{3} \mathrm{~J}_{\mathrm{H}-\mathrm{H}}=6.0,{ }^{3} \mathrm{~J}_{\mathrm{H}-\mathrm{H}}=3.0 \mathrm{~Hz}\right.$ $\left.2 \mathrm{H}, \mathrm{CH}_{\text {arom }}\right), \quad 5.60-5.56\left(\mathrm{~m}, 4 \mathrm{H}, \quad \mathrm{NCH}_{2} \mathrm{CH}_{2} \mathrm{CH}_{3}\right), 4.92-4.98(\mathrm{~m}, 4 \mathrm{H}$, $\left.\mathrm{NCH}_{2} \mathrm{CH}_{2} \mathrm{CH}_{3}\right), 2.55-2.49\left(\mathrm{~m}, 4 \mathrm{H}, \mathrm{NCH}_{2} \mathrm{CH}_{2} \mathrm{CH}_{3}\right), 2.41-2.36(\mathrm{~m}, 4 \mathrm{H}$ $\left.\mathrm{NCH}_{2} \mathrm{CH}_{2} \mathrm{CH}_{3}\right), 1.63\left(\mathrm{~s}, 18 \mathrm{H}, \mathrm{C}\left(\mathrm{CH}_{3}\right)_{3}\right), 1.40\left(\mathrm{t},{ }^{3} \mathrm{~J}_{\mathrm{H}-\mathrm{H}}=7.2 \mathrm{~Hz}, 6 \mathrm{H}\right.$, $\left.\mathrm{NCH}_{2} \mathrm{CH}_{2} \mathrm{CH}_{3}\right), 1.23\left(\mathrm{t},{ }^{3} \mathrm{JH}_{\mathrm{H}}=7.2 \mathrm{~Hz}, 6 \mathrm{H}, \mathrm{NCH}_{2} \mathrm{CH}_{2} \mathrm{CH}_{3}\right) .{ }^{13} \mathrm{C} \mathrm{NMR}(126$ $\left.\mathrm{MHz}, \mathrm{CDCl}_{3}\right)$ : $\delta 181.2$ (Pd- $\left.C_{\text {carbene }}\right), 176.5$ (Pd- $\left.C_{\text {carbene }}\right), 148.8\left(C_{\mathrm{q} p y r}\right)$, $134.9\left(C_{\mathrm{q}}\right), 131.8\left(C_{\mathrm{q} \text { pyr }}\right), 128.9\left(\mathrm{C}_{\mathrm{q} \text { pyr }}\right), 128.3\left(\mathrm{CH}_{\mathrm{pyr}}\right), 122.8\left(\mathrm{CH}_{\text {arom }}\right)$, $122.3\left(\mathrm{CH}_{\text {pyr }}\right), 121.2\left(\mathrm{Cq}_{\mathrm{q} y r}\right), 121.0\left(\mathrm{C}_{\mathrm{q} \text { pyr }}\right), 116.6\left(\mathrm{CH}_{\text {pyr }}\right), 110.6\left(\mathrm{CH}_{\text {arom }}\right)$, $53.7\left(\mathrm{NCH}_{2} \mathrm{CH}_{2} \mathrm{CH}_{3}\right), 50.2\left(\mathrm{NCH}_{2} \mathrm{CH}_{2} \mathrm{CH}_{3}\right), 35.5\left(\mathrm{C}\left(\mathrm{CH}_{3}\right)_{3}\right), 32.0\left(\mathrm{C}\left(\mathrm{CH}_{3}\right)_{3}\right)$ $23.4\left(\mathrm{NCH}_{2} \mathrm{CH}_{2} \mathrm{CH}_{3}\right), 23.2\left(\mathrm{NCH}_{2} \mathrm{CH}_{2} \mathrm{CH}_{3}\right), 12.2\left(\mathrm{NCH}_{2} \mathrm{CH}_{2} \mathrm{CH}_{3}\right), 11.98$ $\left(\mathrm{NCH}_{2} \mathrm{CH}_{2} \mathrm{CH}_{3}\right)$. Anal. Calc. for $\mathrm{PdBr}_{2} \mathrm{~N}_{4} \mathrm{C}_{44} \mathrm{H}_{56}$ (907.19): C, 58.26; $\mathrm{H}, 6.22$; $\mathrm{N}, 6.18$. Found: C, 58.16; H, 6.81; N, 5.51. Electrospray MS (20 V, $\mathrm{m} / \mathrm{z})$ : $866.3\left[\mathrm{M}-\mathrm{Br}+\mathrm{CH}_{3} \mathrm{CN}\right]^{+}$.

General procedure for the synthesis of complexes 3 . The corresponding bis-imidazolium salt ( 1 equiv.), the metal precursor 2 (1 equiv.) and $\mathrm{KO} B \mathrm{Bu}(2.2$ equiv.) were suspended in THF and the reaction was stirred at room temperature overnight. The mixture was filtered through Celite. The solution was concentrated under reduced pressure and the solid was purified by the appropriate methodology.

Synthesis of 3-Et. The reaction was carried out using C-Et $(77.4 \mathrm{mg}$, $0.114 \mathrm{mmol}), 1-\mathrm{Et}(100 \mathrm{mg}, 0.114 \mathrm{mmol})$ and KOtBu $(29.5 \mathrm{mg}, 0.25 \mathrm{mmol})$. The crude was purified by column chromatography. Elution with a mixture 9:1 dichloromethane/hexane afforded the separation of a yellow band that contained compound 3-Et. The desired complex was isolated as a yellow solid after precipitation in a mixture dichloromethane/hexane. Yield: $27 \mathrm{mg}$, $19 \%$. ${ }^{1} \mathrm{H}$ NMR $\left(300 \mathrm{MHz}, \mathrm{CDCl}_{3}\right): \delta 8.82$ (s, $\left.4 \mathrm{H}, \mathrm{CH}_{\text {pyr }}, 4 \mathrm{H}\right), 7.45$ (br s, $4 \mathrm{H}, \mathrm{CH}$ arom), 7.32 (br s, $4 \mathrm{H}, \mathrm{CH}_{\text {arom }}$ ), $5.77\left(\mathrm{q},{ }^{3} \mathrm{~J}-\mathrm{H}=6.5 \mathrm{~Hz}, 8 \mathrm{H}, \mathrm{NCH}_{2} \mathrm{CH}_{3}\right.$ ), $5.01\left(\mathrm{q},{ }^{3} \mathrm{JH}_{\mathrm{H}-\mathrm{H}}=6.7 \mathrm{~Hz}, 8 \mathrm{H}, \mathrm{NCH}_{2} \mathrm{CH}_{3}\right), 2.10\left(\mathrm{t},{ }^{3} \mathrm{~J}_{\mathrm{H}-\mathrm{H}}=6.5 \mathrm{~Hz}, 12 \mathrm{H}\right.$, $\left.\mathrm{NCH}_{2} \mathrm{CH}_{3}\right), 1.86\left(\mathrm{t},{ }^{3} \mathrm{H}-\mathrm{H}=6.7 \mathrm{~Hz}, 12 \mathrm{H}, \mathrm{NCH}_{2} \mathrm{CH}_{3}\right), 1.68\left(\mathrm{~s}, 18 \mathrm{H}, \mathrm{C}\left(\mathrm{CH}_{3}\right)_{3}\right)$. ${ }^{13} \mathrm{C} \mathrm{NMR}\left(75 \mathrm{MHz}, \mathrm{CDCl}_{3}\right): \delta 181.0$ (Pd- $\left.C_{\text {carbene }}\right), 178.8$ (Pd- $\left.C_{\text {carbene }}\right), 149.2$ $\left(C_{\mathrm{q} \text { pyr }}\right), 134.5\left(C_{\mathrm{q}}\right), 129.0\left(C_{\mathrm{q} \text { pyr }}\right), 122.9\left(\mathrm{CH}_{\mathrm{arom}}\right), 121.7\left(C_{\mathrm{q} \text { pyr }}\right), 119.2\left(C_{\mathrm{q}}\right.$ pyr $), 116.2\left(\mathrm{CH}_{\text {pyr }}\right), 110.4\left(\mathrm{CH}_{\text {arom }}\right), 47.2\left(\mathrm{NCH}_{2} \mathrm{CH}_{3}\right), 43.5\left(\mathrm{NCH}_{2} \mathrm{CH}_{3}\right), 35.9$ $\left(\mathrm{C}\left(\mathrm{CH}_{3}\right)_{3}\right), 31.9\left(\mathrm{C}\left(\mathrm{CH}_{3}\right)_{3}\right), 15.2\left(\mathrm{NCH}_{2} \mathrm{CH}_{3}\right), 15.1\left(\mathrm{NCH}_{2} \mathrm{CH}_{3}\right)$. Anal. Calc. for $\mathrm{Pd}_{2} \mathrm{Br}_{4} \mathrm{~N}_{8} \mathrm{C}_{56} \mathrm{H}_{70} \cdot 2 \mathrm{H}_{2} \mathrm{O}$ (1423.72): C, 47.24; $\mathrm{H}, 5.24 ; \mathrm{N}, 7.87$. Found: $\mathrm{C}$,
47.05.14; H, 5.21; N, 7.46. Electrospray MS $(20 \mathrm{~V}, \mathrm{~m} / \mathrm{z}): 1350.0[\mathrm{M}-$ $\mathrm{Br}+\mathrm{MeCN}]^{+}$.

Synthesis of 3-nPr.The reaction was carried out using C- $n \mathrm{Pr}(78.8 \mathrm{mg}$, $0.107 \mathrm{mmol}), 1-n \mathrm{Pr}(100 \mathrm{mg}, 0.107 \mathrm{mmol}$ ) and KOtBu (27.8 mg, 0.24 mmol). Precipitation with a mixture $\mathrm{CH}_{2} \mathrm{Cl}_{2} /$ hexane afforded compound 3$n \mathrm{Pr}$ as a yellow solid. Yield: $100 \mathrm{mg}, 62 \% .{ }^{1} \mathrm{H} \mathrm{NMR}\left(500 \mathrm{MHz}, \mathrm{CDCl}_{3}\right): \delta$ $8.74\left(\mathrm{~s}, 4 \mathrm{H}, \mathrm{CH}_{\text {pyr }}\right), 7.45\left(\mathrm{dd},{ }^{3} \mathrm{JH}_{\mathrm{H}}=6.0 \mathrm{~Hz},{ }^{4} \mathrm{JH}_{\mathrm{H}-\mathrm{H}}=3.1 \mathrm{~Hz}, 4 \mathrm{H}, \mathrm{CH}_{\text {arom }}\right)$, $7.30\left(\mathrm{dd},{ }^{3} \mathrm{~J}_{\mathrm{H}-\mathrm{H}}=6.0 \mathrm{~Hz},{ }^{3} \mathrm{~J}_{\mathrm{H}-\mathrm{H}}=3.1 \mathrm{~Hz}, 4 \mathrm{H}, \mathrm{CH}_{\text {arom }}\right), 5.64-5.60(\mathrm{~m}, 8 \mathrm{H}, \mathrm{N}-$ $\left.\mathrm{CH}_{2}-\mathrm{CH}_{2}-\mathrm{CH}_{3}\right), 4.92-4.89\left(\mathrm{~m}, 8 \mathrm{H}, \mathrm{N}-\mathrm{CH}_{2}-\mathrm{CH}_{2}-\mathrm{CH}_{3}\right), 2.57-2.49 \mathrm{~m}, 8 \mathrm{H}, \mathrm{N}-$ $\left.\mathrm{CH}_{2}-\mathrm{CH}_{2}-\mathrm{CH}_{3}\right), 2.42-2.35\left(\mathrm{~m}, 8 \mathrm{H}, \mathrm{N}-\mathrm{CH}_{2}-\mathrm{CH}_{2}-\mathrm{CH}_{3}\right), 1.68\left(\mathrm{~s}, 18 \mathrm{H}, \mathrm{C}\left(\mathrm{CH}_{3}\right)_{3}\right)$, $1.41\left(\mathrm{t},{ }^{3} \mathrm{JH}_{\mathrm{H}}=7.4 \mathrm{~Hz}, 12 \mathrm{H}, \mathrm{N}-\mathrm{CH}_{2}-\mathrm{CH}_{2}-\mathrm{CH}_{3}\right), 1.23\left(\mathrm{t},{ }^{3} \mathrm{JH}_{\mathrm{H}-\mathrm{H}}=7.4 \mathrm{~Hz}, 12 \mathrm{H}\right.$, $\left.\mathrm{N}-\mathrm{CH}_{2}-\mathrm{CH}_{2}-\mathrm{CH}_{3}\right) .{ }^{13} \mathrm{C} \mathrm{NMR}\left(126 \mathrm{MHz}, \mathrm{CDCl}_{3}\right): \delta 181.0$ (Pd-C carbene), 178.6 ( $\left.\mathrm{Pd}-C_{\text {carbene }}\right), 149.0\left(C_{\text {q pyr }}\right), 135.0\left(C_{\mathrm{q}}\right), 129.1\left(C_{\text {q pyr }}\right), 122.8\left(\mathrm{CH}_{\text {arom }}\right), 121.8$ ( $\left.C_{\text {q pyr }}\right), 119.3\left(C_{\text {q pyr }}\right), 116.2\left(C \mathrm{H}_{\text {pyr }}\right), 110.7\left(C \mathrm{H}_{\text {arom }}\right), 54.0\left(\mathrm{NCH}_{2} \mathrm{CH}_{2} \mathrm{CH}_{3}\right)$,

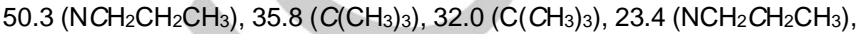
$23.2\left(\mathrm{NCH}_{2} \mathrm{CH}_{2} \mathrm{CH}_{3}\right), 12.20\left(\mathrm{NCH}_{2} \mathrm{CH}_{2} \mathrm{CH}_{3}\right), 11.7\left(\mathrm{NCH}_{2} \mathrm{CH}_{2} \mathrm{CH}_{3}\right)$. Anal. Calc. for $\mathrm{Pd}_{2} \mathrm{Br}_{4} \mathrm{~N}_{8} \mathrm{C}_{64} \mathrm{H}_{86} .2 \mathrm{H}_{2} \mathrm{O}$ (1535.93): C, 50.05; H, 5.91; N, 7.30. Found: C, 50.14; H, 5.40; N, 6.87. Electrospray MS (20 V, m/z): 1460.3 $[\mathrm{M}-\mathrm{Br}+\mathrm{MeCN}]^{+}$.

\section{Acknowledgments}

We gratefully acknowledge financial support from the Universitat Jaume I (UJI-B2017-07 and UJI-B2018-46). Sergio Gonell thanks the Ministerio de Ciencia e Innovación for a fellowship. The authors are grateful to the Serveis Centrals d'Instrumentació Científica (SCIC) of the Universitat Jaume I for providing us with all characterization techniques.

Keywords: palladium, aromatic, N-heterocyclic carbene, monometallic, dimetallic

[1] E. K. van den Beuken and B. L. Feringa, Tetrahedron 1998, 54, 1298513011.

[2] J. A. Mata, F. E. Hahn and E. Peris, Chem. Sci. 2014, 5, 1723-1732.

[3] I. Bratko and M. Gomez, Dalton Trans. 2013, 42, 10664-10681.

[4] W. A. Herrmann and C. Kocher, Angew. Chem., Int. Edit. Engl. 1997, 36, 2163-2187.

[5] D. Bourissou, O. Guerret, F. P. Gabbai and G. Bertrand, Chem. Rev. 2000, 100, 39-91.

[6] M. Poyatos, J. A. Mata and E. Peris, Chem. Rev. 2009, 109, 3677-3707

[7] R. Visbal and M. C. Gimeno, Chem. Soc. Rev. 2014, 43, 3551-3574.

[8] K. A. Williams and C. W. Bielawski, Chem. Commun. 2010, 46, 51665168.

[9] S. Gonell, M. Poyatos and E. Peris, Angew. Chem., Int. Ed. 2013, 52, 7009-7013.

[10] A. J. Boydston, K. A. Williams and C. W. Bielawski, J. Am. Chem. Soc. 2005, 127, 12496-12497.

[11] E. Mas-Marza, J. A. Mata and E. Peris, Angew. Chem., Int. Ed. 2007, 46, 3729-3731.

[12] O. Guerret, S. Sole, H. Gornitzka, M. Teichert, G. Trinquier and G. Bertrand, J. Am. Chem. Soc. 1997, 119, 6668-6669.

[13] N. Vujkovic, V. Cesar, N. Lugan and G. Lavigne, Chem.-Eur. J. 2011, 17, 13151-13155.

[14] D. M. Khramov, A. J. Boydston and C. W. Bielawski, Angew. Chem., Int. Ed. 2006, 45, 6186-6189.

[15] D. Tapu, Z. McCarty and C. McMillen, Chem. Commun. 2014, 50, 4725 4728

[16] A. Prades, E. Peris and M. Alcarazo, Organometallics 2012, 31, 46234626. 
[17] G. Guisado-Barrios, J. Hiller and E. Peris, Chem.-Eur. J. 2013, 19, 10405-10411.

[18] S. Gonell and E. Peris, Acs Catalysis 2014, 4, 2811-2817.

[19] S. Gonell, M. Poyatos and E. Peris, Chem.-Eur. J. 2014, 20, 9716-9724.

[20] S. Ibañez, A. Guerrero, M. Poyatos and E. Peris, Chem.-Eur. J. 2015, 21 10566-10575.

[21] S. Langbein, H. Wadepohl and L. H. Gade, Organometallics 2016, 35 , 809-815.

[22] H. Valdes, M. Poyatos and E. Peris, Organometallics 2015, 34, 17251729.

[23] M. Meier, T. T. Y. Tan, F. E. Hahn and H. V. Huynh, Organometallics 2017, 36, 275-284

[24] A. Carter, A. Mason, M. A. Baker, D. G. Bettler, A. Changas, C. D. McMillen and D. Tapu, Organometallics 2017, 36, 1867-1872.

[25] E. Peris, Chem. Commun. 2016, 52, 5777-5787.

[26] F. E. Hahn, L. Wittenbecher, D. Le Van and R. Frohlich, Angew. Chem., Int. Ed. 2000, 39, 541-544.

[27] P. Bazinet, G. P. A. Yap and D. S. Richeson, J. Am. Chem. Soc. 2003 125, 13314-13315.

[28] D. Tapu, C. Owens, D. VanDerveer and K. Gwaltney, Organometallics 2009, 28, 270-276.

[29] K. V. Vasudevan, R. R. Butorac, C. D. Abernethy and A. H. Cowley, Dalton Trans. 2010, 39, 7401-7408.

[30] D. Tapu, Z. McCarty, L. Hutchinson, C. Ghattas, M. Chowdhury, J. Salerno and D. VanDerveer, J. Organomet. Chem. 2014, 749, 134-141.

[31] H. Valdes, M. Poyatos and E. Peris, Organometallics 2014, 33, 394-401.

[32] H. Valdes, M. Poyatos and E. Peris, Inorg. Chem. 2015, 54, 3654-3659.

[33] S. Saravanakumar, A. I. Oprea, M. K. Kindermann, P. G. Jones and J. Heinicke, Chem.-Eur. J. 2006, 12, 3143-3154.

[34] H. V. Huynh, Y. Han, J. H. H. Ho and G. K. Tan, Organometallics 2006 , 25, 3267-3274.

[35] P. Mathew, A. Neels and M. Albrecht, J. Am. Chem. Soc. 2008, 130 , 13534-13535.

[36] L. Palacios, M. Jose Artigas, V. Polo, F. J. Lahoz, R. Castarlenas, J. J. Perez-Torrente and L. A. Oro, Acs Catalysis 2013, 3, 2910-2919.

[37] Y. A. Han, D. Yuan, Q. Q. Teng and V. H. Han, Organometallics 2011, 30, 1224-1230.

[38] H. M. J. Wang and I. J. B. Lin, Organometallics 1998, 17, 972-975.

[39] D. Nuevo, S. Gonell, M. Poyatos and E. Peris, Chem.-Eur. J. 2017, 23, 7272-7277.

[40] H. V. Huynh, Y. Han, R. Jothibasu and J. A. Yang, Organometallics 2009, 28, 5395-5404.

[41] H. V. Huynh, J. H. H. Ho, T. C. Neo and L. L. Koh, J. Organomet. Chem 2005, 690, 3854-3860.

[42] Q. Q. Teng and H. V. Huynh, Dalton Trans. 2017, 46, 614-627.

[43] Q. Q. Teng and H. V. Huynh, Inorg. Chem. 2014, 53, 10964-10973.

[44] S. Gonell, M. Poyatos and E. Peris, Dalton Trans. 2016, 45, 5549-5556.

[45] J. A. V. Er, A. G. Tennyson, J. W. Kamplain, V. M. Lynch and C. W. Bielawski, Eur. J. Inorg. Chem. 2009, 1729-1738. 
Entry for the Table of Contents (Please choose one layout)

Layout 1:

\section{FULL PAPER}

Palladium complexes decorated with two types of aromatic

$\mathrm{N}$-heterocyclic carbene (NHC) ligands of different size have been prepared starting from dinuclear palladium complexes.

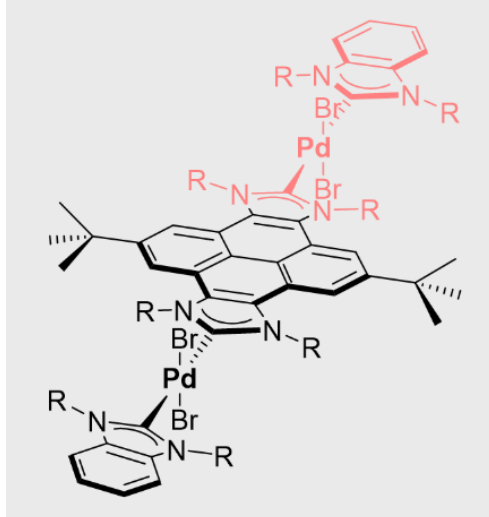

Combining aromatic NHC ligands

Sergio Gonell, ${ }^{*}$ Eduardo Peris, and Macarena Poyatos*

Page No. - Page No.

Structural features of mono and dimetallic complexes of palladium combining two types of aromatic NHC ligands

*one or two words that highlight the emphasis of the paper or the field of the study 